\title{
Dysregulated MicroRNA Expression in Irritable Bowel Syndrome
}

\author{
Jung Ho Park \\ Department of Internal Medicine, Kangbuk Samsung Hospital, Sungkyunkwan University College of Medicine, Seoul, Korea
}

\begin{abstract}
Article: Association of the serotonin receptor 3E gene as a functional variant in the microRNA-510 target site with diarrhea predominant irritable bowel syndrome in Chinese women

Zhang Y, Li Y, Hao Z, Li X, Bo P, Gong W

(J Neurogastroenterol Motil 2016;22:272-281)
\end{abstract}

Irritable bowel syndrome (IBS) is one of the most common functional gastrointestinal (GI) disorders. The cause of IBS remains unknown and seems to be multifactorial. Several mechanisms, infection, food, and psychiatric factors have been suggested as possible etiologic links to the development of $\operatorname{IBS}^{1}$ and also, there has been increasing evidence of a genetic contribution in IBS. IBS aggregates in families, and the concordance for monozygotic twins is almost twice as great as that for dizygotic twins. ${ }^{2}$ Serotonin receptor type $3\left(5-\mathrm{HT}_{3}\right)$ is an important neurotransmitter in the gut, and abnormal $5-\mathrm{HT}_{3}$ signaling has been implicated in a number functional GI disorders, including IBS. In the current issue of this journal, Zhang et $\mathrm{al}^{3}$ tried to determine the relationship of the polymorphism both to $5-\mathrm{HT}_{3 \mathrm{E}}$ expression in the intestine and to the occurrence of Chinese functional gastrointestinal disorders. They concluded that the single-nucleotide polymorphisms rs56109847 led to reduced microRNA (miRNA) binding and overexpression of the target gene in intestinal cells, thereby increasing diarrhea predominant IBS (IBS-D) risk in the Chinese Han population. The decreased expression of miRNA-510 might contribute to IBSD. MicroRNAs are involved in the regulation of normal biological functioning process such as cellular development, differentiation, proliferation, apoptosis, and metabolism. Therefore, dysregulation of miRNA can result in the development of human diseases, including GI disorders. A recent study has reported that microRNArelated expression regulation of a serotonin receptor gene with a cis-regulatory variant affected this regulation and appeared to be associated with female IBS- $\mathrm{D}^{4}$ and miRNA-29a effects on intestinal membrane permeability through its regulation of glutamate-ammonia ligase gene. ${ }^{5}$ The regulation of miRNA-510 on 5- $\mathrm{HT}_{3 \mathrm{E}}$ expression and the possible association between $5-\mathrm{HT}_{3 \mathrm{E}}$ single nucleotide polymorphism rs56109847 and IBS-D are interesting findings of this study. However, the small sample size and study population that is restricted to women are the limitations of this study. And also, as in the analysis about a genetic polymorphism in the genetic encoding for activity of the serotonin transporter protein, ${ }^{6}$ more investigations might be needed in the future for the confirmation of this relationship.

\section{Received: March 14, 2016 Revised: None Accepted: March 24, 2016}

() This is an Open Access article distributed under the terms of the Creative Commons Attribution Non-Commercial License (http://creativecommons. org/licenses/by-nc/4.0) which permits unrestricted non-commercial use, distribution, and reproduction in any medium, provided the original work is properly cited.

*Correspondence: Jung Ho Park, MD Department of Internal Medicine, Kangbuk Samsung Hospital, Sungkyunkwan University School of Medicine, 29, Saemunan-ro, Jongno-gu, Seoul 03181, Korea

Tel: +82-2-2001-2059, Fax: +82-2-2001-2485, E-mail: pjho3@hotmail.com 
Financial support: None.

\section{Conflicts of interest: None.}

\section{References}

1. Chey WD, Kurlander J, Eswaran S. Irritable bowel syndrome: a clinical review. JAMA 2015;313:949-958.

2. Soares RL. Irritable bowel syndrome: a clinical review. World J Gastroenterol 2014;20:12144-12160.

3. Zhang Y, Li Y, Hao Z, Li X, Bo P, Gong W. Association of the serotonin receptor $3 \mathrm{E}$ gene as a functional variant in the microRNA-510 target site with diarrhea predominant irritable bowel syndrome in Chinese women. J Neurogastroenterol Motil 2016;22:272-281.

4. Kapeller J, Houghton LA, Mönnikes H, et al. First evidence for an association of a functional variant in the microRNA-510 target site of the serotonin receptor-type $3 \mathrm{E}$ gene with diarrhea predominant irritable bowel syndrome. Hum Mol Genet 2008;17:2967-2977.

5. Zhou Q, Souba WW, Croce CM, Verne GN. MicroRNA-29a regulates intestinal membrane permeability in patients with irritable bowel syndrome. Gut 2010;59:775-784.

6. Van Kerkhoven LA, Laheij RJ, Jansen JB. Meta-analysis: a functional polymorphism in the gene encoding for activity of the serotonin transporter protein is not associated with the irritable bowel syndrome. Aliment Pharm Ther 2007;26:979-986. 